
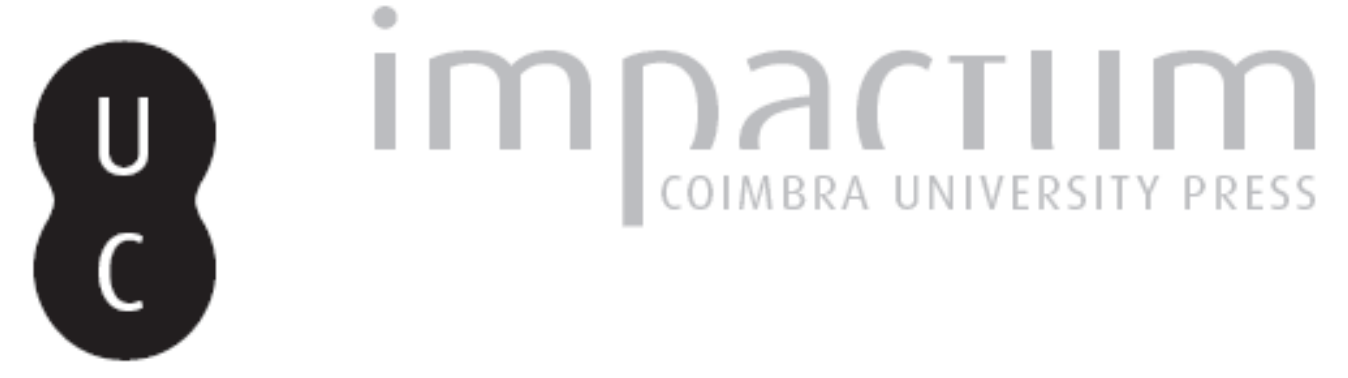

\title{
[Recensão a] TAUSIET, María, Urban Magic in Early Modern Spain: Abracadabra Omnipotens
}

\author{
Autor(es): $\quad$ Leitão, J. Vieira
}

Publicado por: Imprensa da Universidade de Coimbra

URL

persistente:

URI:http://hdl.handle.net/10316.2/43835

DOI:

DOI:https://doi.org/10.14195/2183-8925_36_17

Accessed : $\quad$ 26-Apr-2023 07:55:22

A navegação consulta e descarregamento dos títulos inseridos nas Bibliotecas Digitais UC Digitalis, UC Pombalina e UC Impactum, pressupõem a aceitação plena e sem reservas dos Termos e Condições de Uso destas Bibliotecas Digitais, disponíveis em https://digitalis.uc.pt/pt-pt/termos.

Conforme exposto nos referidos Termos e Condições de Uso, o descarregamento de títulos de acesso restrito requer uma licença válida de autorização devendo o utilizador aceder ao(s) documento(s) a partir de um endereço de IP da instituição detentora da supramencionada licença.

Ao utilizador é apenas permitido o descarregamento para uso pessoal, pelo que o emprego do(s) título(s) descarregado(s) para outro fim, designadamente comercial, carece de autorização do respetivo autor ou editor da obra.

Na medida em que todas as obras da UC Digitalis se encontram protegidas pelo Código do Direito de Autor e Direitos Conexos e demais legislação aplicável, toda a cópia, parcial ou total, deste documento, nos casos em que é legalmente admitida, deverá conter ou fazer-se acompanhar por este aviso.

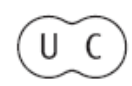



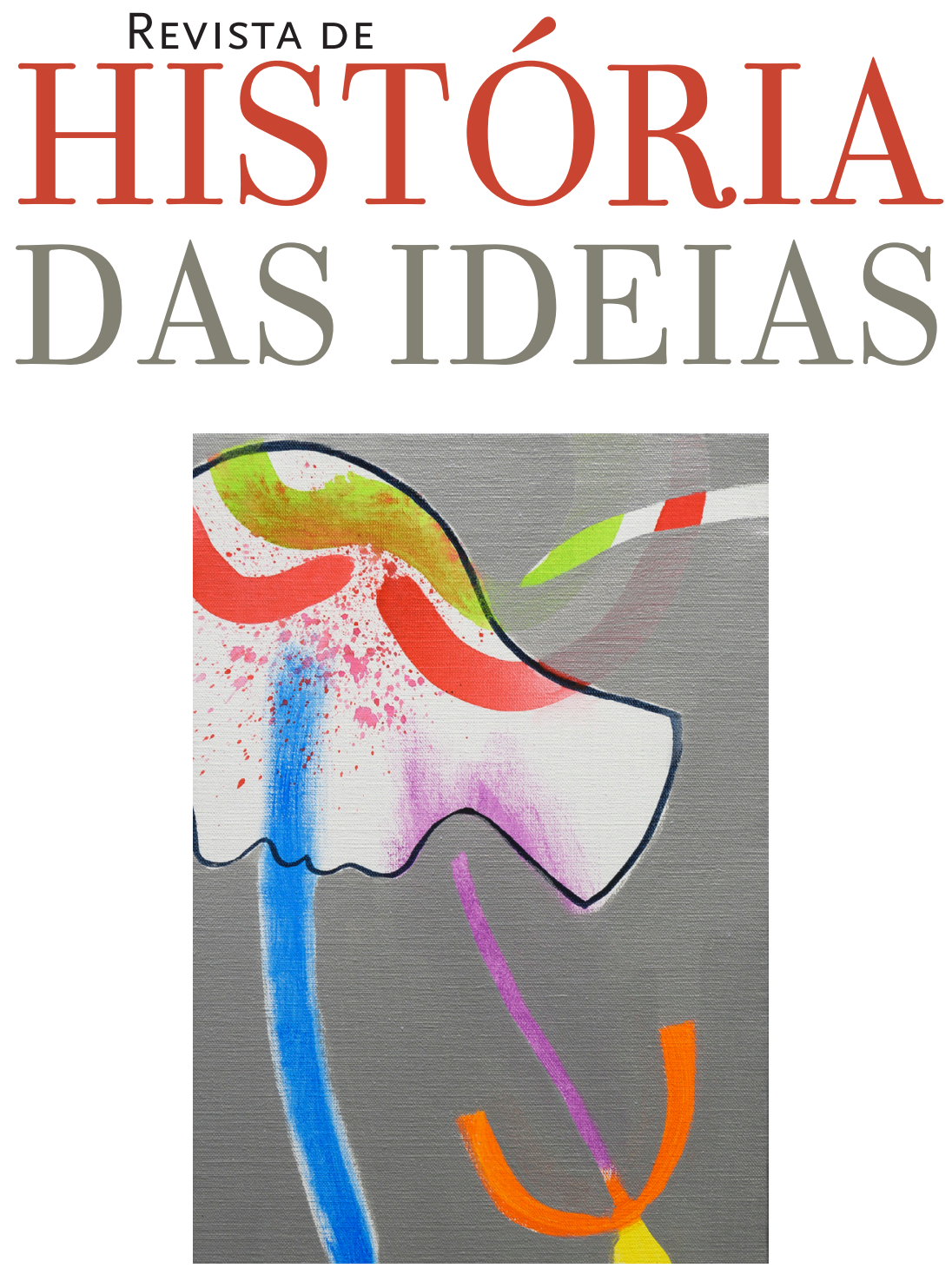

Religiões e Culturas

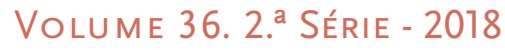


a campanha redundou num enorme fracasso consumado junto às muralhas de Damasco (p. 308-310).

De um modo geral, podemos afirmar que a presente obra deverá constituir uma referência, não só para o estudo deste episódio em particular, mas também para a história militar medieval, devido à amplitude dos temas que trata (abastecimento, armamento, tática, efetivos, entre outros). Nota-se que existe a preocupação de escrever para um público mais vasto, o que explicará a concisão das notas apresentadas no final. Nada, porém, que afete o conteúdo do trabalho. As gravuras das páginas centrais são bem escolhidas, assim como a imagem da capa: uma reprodução da aguarela de Roque Gameiro onde se evoca a conquista (em versão algo fantasiada...) da cidade de Lisboa. Em suma, a integração deste momento decisivo num contexto mais abrangente valoriza o livro e, acima de tudo, permite que o leitor o associe à grande epopeia do seu tempo - as Cruzadas.

JOÃO NISA
Doutorando em História na FLUC, investigador do CHSC
joaonisa1984@gmail.com
ORCID: 0000-0001-7698-7567
https://doi.org/10.14195/2183-8925_36_16

María Tausiet, Urban Magic in Early Modern Spain: Abracadabra Omnipotens, Hampshire: Palgrave Macmillan 2014, 254 p. ISBN: 978-1403-99566-7 (Hardback).

Academic studies on Iberian magic and esotericism are rarely found in English, even though in recent years, quite a few have been produced in their original languages. The translation and publication of María Tausiet's 2007 book Abracadabra Omnipotens: Magia urbana en Zaragoza en la Edad Moderna by Palgrave Macmillan, now under the title Urban Magic in Early Modern Spain, is therefore a most welcome event, especially from an author with such a remarkable body of work.

Unfortunately, an initial criticism needs to be made regarding this book's title, even though it by no means detracts from its value. As implied in its original title, the book mostly focuses on the situation in the city of Saragossa, which Tausiet describes in terms of its historical, religious and 
urban uniqueness in the prologue. As such, the change from «Zaragoza» to «Spain» in the current translation, which was likely an editorial choice rather than the responsibility of the author, is certainly odd. To some extent it may even be misleading, bordering on a false advertisement, to suggest that the book aims to cover magic in Spain while it is actually solely devoted to a single Spanish city with very particular social and historical circumstances.

Where the book's content is concerned, chapter one continues the thread of the prologue, expanding on the history of Saragossa as a cultural hub of syncretic Christian, Jewish and Muslim knowledge. It describes how the expulsion or forced conversion of its non-Christian population changed this situation and how Saragossa acquired its centrality in the region, attracting a constant flow of immigrants from the Mediterranean coast and southern France. The description of the three overlapping judicial systems of the secular, episcopalian and inquisitorial courts of Spain, all of which played a part in dealing with cases of magic and witchcraft, is especially relevant in chapter one. Tausiet posits that at least in the Early Modern period, the centralized episcopalian and inquisitorial courts displayed greater leniency towards witchcraft and magic, frequently releasing their accused with light penalties for fraud or deception. Interestingly, it is in the records of the secular courts, which were much more active in rural areas, that reports of torture and execution can be found, thus dispelling the common popular misconceptions of the Spanish Inquisition.

The following three chapters focus on particular aspects of magical practice. In particular, chapter two focuses on what might be called «high» or «ritual» magic, covering the very relevant aspect of magical treasure hunting, a hallmark of Iberian magic. Here, Tausiet's micro-historical approach, dealing with very particular cases of known practitioners, offers a remarkably rich and vivid view of the topic by emphasizing the circulation of foreign knowledge and the personal networks of individuals associated with this practice. Crowning this effort is the impressive amount of insightful detail which would have been lost had the author not used this particular way of presenting her information.

Chapter three examines the other side of the magical field, dealing with love and subjugation magic. An interesting point is raised here regarding the dynamics of the cases analyzed, both in this and in the previous chapter. A theme which is recurrent in this study is what appears to be a certain gender divide between the two aspects of wealth and love/erotic magic, although both aspire to the same goal of financial stability, notably finding 
treasure for men and finding a man for women. Noteworthy is the stark difference pointed out in practical methodology, ingredients and overall rational between each of these forms of magic. The social component of the female world is also given particular attention here, as the urban magic underworld seems to allow for a cathartic outlet of frustrated feelings, in turn generating a support network of practitioners and clients.

Chapter four focuses on semi-sanctioned magic workers, Saludadores. An interesting point made here is the contrast between Saludador practices, which are apparently exclusive to men, and witchcraft, mostly associated with women, and how one was believed to be the method of combating the other. Still, even if this chapter is one of the most interesting, it is somewhat compromised by the fact that Tausiet's description of the Saludador seems to be an oversimplified generalization based on a very narrow set of samples. Although it is true that this would be somewhat beyond the scope of this book, this chapter would probably benefit from a comparison of Saludador practices from other regions of Iberia.

The following two chapters focus on the social aspects of magic inside and outside the city. The fifth describes the city as a place of refuge for those suspected of magic, be they escaping rural secular courts or seeking lodgings in one of the many social institutions accessible through the inquisitional courts. The sixth chapter strives to contrast the concepts and approaches to magic/sorcery in the rural and the urban worlds, although it suffers from a lack of reliable sources and reports on the rural side.

The book lastly ends with a short epilogue in which the author offers an analysis of magic and religion in Saragossa in times of plague. Although focusing on very particular circumstances, the points underlined by Tausiet succeed in transmitting the ingrained nature of magic in Early Modern Saragossan society and describing how easily this overlaps and associates with orthodox religious practices as a defense against disease. In keeping with that presented by the book as a very relevant topic, this particular analysis also highlights gender tensions, with men restraining from sexual contact with women during times of contagion, and, due to this, women resorting to love or erotic magic.

As mentioned, the book is a precious and welcome addition to the international field, offering a wealth of unpublished information and reports from an understudied region. However, it seems to suffer from a systematic shortcoming. While this does not impact too deeply on the book's main theses, on examining the analysis of some of the reports or 
transcribed sorceries, there appears to be a lack of attention to Spanish or Iberian folklore. Paradigmatic examples of this blind spot are the mentions of buried Moorish treasure, which the author appears to associate with the banishment of Morisco populations from Spain in 1610, rather than with the mythical narratives of the Reconquista and the pan-Iberian folkloric figure of the Enchanted Moor. This confusion is indeed difficult to understand, as, even if the author is not a folklorist, mentions of Moorish buried treasure predating 1610 can be easily found in Iberian written sources at least as early as the Codex Calixtinus from the $12^{\text {th }}$ century.

One other such example is Tausiet's quoting of the Libro Magno de San Cipriano o Tesoro del Hechicero, a Spanish grimoire. This book is mentioned in order to offer context for spirit communication and the use of magical circles in the early modern period, but there seems to be a disregard for the fact that this is actually a late $19^{\text {th }}$ or early $20^{\text {th }}$ century book composed by the theosophist Alfredo Rodríguez Aldao from fragments of the Portuguese $O$ Grande Livro de São Cipriano (from the mid $19^{\text {th }}$ century) and the French Grand Grimoire. While this does not invalidate the author's point, it reveals a degree of unfamiliarity with the complex variations of magical literature in Iberia and, given these timeframes, Tausiet's quoting of the Libro Magno de San Cipriano becomes as relevant for the understanding of early modern magical practices as the quoting of any other $19^{\text {th }}$ century Occult Revival author. In fact, the book's dealing with magical literature and ritual is somewhat sketchy, as Tausiet seems to suggest that the "original» significance of such magical operations had been lost by the time they were performed by her analyzed subjects, and that these individuals were drawing from a pool of «imprecise beliefs». The basis on which this assertion is made is unclear; a judgment of «precise» or «imprecise» belief implies that a concrete theological position and an acceptance of the existence of «true precise belief», by which comparison and contrast can be made, was assumed by Tausiet. For a conscientious historian, this is quite difficult to sustain. It is likely that this is once again related to the lack of relevance given to folk culture, as well as an absence of understanding of the dynamics of cultural construction of authority and significance.

What can be possibly concluded from this is that, while Tausiet is a remarkable researcher and historian, folk culture and religion are not within her comfort zone. This shortcoming, given the scarcity of English information on this region, is potentially damaging to the field, as it leads to her offering a distorted and incomplete view of Iberian magical culture. 
In brief, if one is not yet familiar with Iberian magic and folklore, the book at issue is about one hundred pages too short; the author has left out many points which are fundamental for the accurate interpretation of her sources. Otherwise though, a wealth of rare and precious information can be extracted from this work. Overall, it is an extremely worthy and long overdue addition to the international study of religion, esotericism and magic, and offers some excellent insights into the Iberian magical landscape. Hopefully this book will be the first of many and we will soon be seeing María Tausiet's remaining books follow the same path.

J.VIEIRA LEITÃO
jose.cv.leitao@gmail.com
Universidade de Coimbra, Faculdade de Letras
Orcid.org/0000-0001-7456-5045
https://doi.org/10.14195/2183-8925_36_17

Miriam Halpern Pereira, A Primeira República Portuguesa. Na fronteira do liberalismo e da democracia, Lisboa: Gradiva, 2016, 216 p. ISBN: 9789896167295

O livro de Miriam Halpern Pereira é um estudo interpretativo e sintético sobre a história da Primeira República Portuguesa, definida por muitos historiadores como um regime demoliberal. Não sendo uma obra de investigação, não traz grandes novidades temáticas, mas tem a clareza de um raciocínio límpido, que sabe ler a história com grande maturidade e que vai à procura de novos leitores, não se cingindo a um público meramente universitário. Também não se trata de um mero estudo de divulgação, embora a autora escreva para o grande público. Entrando na «polémica apaixonada» ainda hoje existente sobre a compreensão da República, a autora afasta-se daqueles que continuam a ver o regime como uma fase histórica caracterizada pela «balbúrdia», uma imagem criada pelo Salazarismo, especialmente na sua imprensa; também se distancia do carácter apologético do Regime levado a cabo por outras figuras da nossa historiografia mais republicana e de raiz jacobina. Miriam Pereira afasta-se das duas correntes historiográficas opostas a respeito da I Republica e assume uma posição isenta e objetiva, embora o carácter progressista da sua formação historiográfica não esteja ausente do texto interpretativo que produziu. A seu ver, o regime foi aquilo 